\title{
Elaborasi Penggunaan Istilah Covid-19 Terhadap Pemahaman Masyarakat
}

\author{
Sri Widiastutik $^{1}$, I Putu Robin Laksamana Putra ${ }^{2}$, Arti Amartya Pratiwi ${ }^{3}$ \\ ${ }^{1}$ Stmik Stikom Indonesia \\ e-mail: sriwidiastutik@ stiki-indonesia.ac.id \\ ${ }^{2}$ Stmik Stikom Indonesia \\ e-mail: ikarua19@gmail.com \\ ${ }^{3}$ Stmik Stikom Indonesia \\ e-mail: artiamartya999@gmail.com
} Cara Sitasi: Sri W , I Putu RLP, Arti AP (2021) Elaborasi Penggunaan Istilah Covid-19 Terhadap
Pemahaman Masyarakat, 2021 21(2), $87-91$ Retrieved from https://doi.org/10.31294/jc.v19i2

\begin{abstract}
The COVID-19 pandemic that is threatening the world has caused anxiety for all parties, including the people in Denpasar City. Various attempts have been made to make the situation stable, one way is to share information within a positive elaboration terminology. The information is certainly delivered by foreign words that are currently so prevalent, and appears in one click through the Google search engine. In order to convey the intent and meaning that can be properly channeled to all levels of society, Policies related to handling the COVID19 pandemic through the elaboration of several foreign terms such as lockdown, swab test, social distancing, etc. are required. This study aimed to find out how the foreign words can be well accepted by the community without risking the existence of Indonesian language. As a descriptive qualitative method, the main data is Covid terms that are informed to the public in Denpasar are collected using a polling technique through randomly distributing questionnaires and simulation. Finding data was used survey \& observation methods, as well as documentation. It is hoped public can understand and implement the appeal as expected by the government, without reducing the existence of good and correct Indonesian.
\end{abstract}

Keywords: elaboration, foreign words, covid term

\section{PENDAHULUAN}

Alat komunikasi antar manusia yang umum dipakai adalah bahasa, baik tulis maupun lisan. Setiap negara atau daerah mempunyai alat komunikasi berupa bahasa yang sepakat digunakan sebagai pemersatu bangsa. Bangsa Indonesia pada akhirnya sepakat untuk menggunakan satu bahasa persatuan, yakni bahasa Indonesia. Dalam perkembangannya bahasa bersifat dinamis, bisa berubah dan berkembang kapan saja. Bila dielaborasi berdasarkan situasi pandemi covid-19, dapat kita lihat bahwa sifat bahasa yang dinamis sangat mencolok dirasakan bagi masyarakat di Denpasar.

Dampak wabah Covid-19 di Bali ini tidak hanya di bidang ekonomi, pariwisata, transportasi, bahkan sangat berdampak di bidang bahasa, khususnya dampak terhadap eksistensi bahasa Indonesia yang mulai diragukan sejak semakain banyak bermunculan istilah asing yang dikemas sebagai informasi penanganan pandemi Covid-19. Beberapa istilahistilah asing yang digunakan tersebut merupakan istilah umum yang ditetapkan oleh organisasi kesehatan dunia (WHO), dan dengan resmi telah menetapkan Covid-19 sebagai sebutan untuk pandemi virus Corona. Kemudian ditindaklanjuti oleh pemerintah dan pihak-pihak berwenang dalam menetapkan kebijakan terhadap penggunaan istilahistilah asing ini. Menko Polhukam Mahfud $\mathrm{Md}$ (detiknews: 23 Maret 2020) mengatakan bahwa pemerintah mengubah himbauan dalam mencegah penyebaran virus Corona dari "pembatasan interaksi sosial (social distancing)" menjadi "menjaga jarak secara fisik (physical distancing)". Penyebutan physical distancing dirasa lebih cocok untuk konteks menjaga jarak fisik terkait pencegahan Covid-19. Kasus sederhana ini kiranya dapat menjadi contoh tentang betapa pentingnya perhatian terhadap penggunaan istilah-istilah asing yang bagaimanapun harus tetap mengutamakan fungsi, makna, rasa bahasa serta kesesuaian budaya yang terjadi di Indonesia.

Istilah-istilah yang secara masif digunakan dalam hidup sehari-hari ini, merupakan istilah dari dan dipengaruhi oleh bahasa asing, maupun akronim, seperti: WFH (work from home), suspect, lockdown, social distancing, imported case, local transmission, padahal beberapa istilah asing tersebut sebenarnya 
sudah ada padanannya dalam bahasa Indonesia. Istilah lockdown, sanitizer, dropled, dan sebagainya lebih sering digunakan daripada kata "karantina wilayah", "penyanitasi tangan", "percikan". Bahkan kosakata yang berupa singkatan juga menggunakan bahasa Inggris, seperti WFH (work from home) dan WFO (work from office), walaupun sebenarnya bisa menggunakan bahasa Indonesia, yakni KDR (kerja dari rumah) dan KDK (kerja dari kantor).

Penggunaan istilah tersebut belum tentu bisa dipahami oleh semua lapisan masyarakat, apalagi masyarakat yang tingkat pendidikannya rendah dan selama ini susah untuk mengakses informasi, tentu penggunaan bahasa asing ini akan sulit dipahami mereka. Bahkan ada juga sebagian masyarakat yang masih sulit memahami informasi dalam bahasa Indonesia. Berdasarkan fenomena tersebut, tim peneliti merumuskan permasalahan, adalah: apa saja jenis istilah asing yang diinformasikan pemerintah kepada masyarakat? Apakah istilah asing tersebut dapat dipahami oleh masyarakat di Denpasar? Bagaimana dampak penggunaan istilah asing pada masa pandemi ini terhadap eksistensi bahasa Indonesia? Diharapkan hasil penelitian ini dapat meluruskan kembali dan menjawab keraguan terhadap relevansi peran dan fungsi Bahasa Indonesia sebagai identitas bangsa, masyarakat Denpasar selalu cerdas dan tidak terpapar endemik bahasa asing yang mempengaruhi praktik berbahasa yang baik dan benar. Hal yang terpenting adalah masyarakat bisa memahami dan melaksanakan himbauan seperti yang diharapkan oleh pemerintah, dalam hal ini tim gugus tugas penanganan Covid-19.

\section{Elaborasi}

Dalam kamus KBBI, kata elaborasi/ela $\cdot$ bo $\cdot r a \cdot s i / /$ laborasi/ $n$ berarti penggarap an secara tekun dan cermat. Bila dielaborasi berdasarkan situasi sekarang secara khusus dalam kaitannya dengan pandemi covid-19, dapat kita lihat bahwa sifat bahasa yang dinamis sangat nampak dan mencolok dirasakan. Dengan merebaknya pandemi covid-19, merebak pula istilah-istilah baru dalam hidup masyarakat indonesia. Istilah-istilah itu banyak yang merupakan istilah dari dan dipengaruhi oleh bahasa asing juga ada yang berupa akronim maupun istilah-istilah asing seperti, WFH (work from home), suspect, lockdown, social distancing, imported case, local transmission.

Alfarisy (2020) menegaskan kembali amanat dari UU no 24.2009 bahwa "Utamakan Bahasa Indonesia, Kuasai Bahasa Asing, Lestarikan Bahasa Daerah" yang mengindikasikan bahwa sebagai bangsa Indonesia kita dianjurkan untuk menggunakan bahasa persatuan di ruang publik maupun komunikasi. Di sisi lain pandemi virus korona atau Covid19 telah membawa banyak dampak pada kehidupan berbangsa termasuk bahasa. Virus yang berasal dari negara asing dan menjangkiti hampir seluruh bagian bumi membawa berbagai istilah asing masuk ke bangsa ini. Pada saat inilah kebijakan pemerintah Indonesia tentang bahasa Indonesia diuji karena pejabat pemerintah seringkali menggunakan istilah asing dalam menjelaskan situasi.

\section{Bahasa Bersifat Dinamis}

Harus diakui bahwa dalam perkembangannya, bahasa tidak dapat mengelak dari sifat dinamis yang ada dalam dirinya. Artinya, bahasa tidak terlepas dari kemungkinan untuk berubah dan berkembang. Perubahan dan perkembangan bahasa dapat terjadi pada tataran fonologis, morfologis, sintaksis, dan semantik (Yohanes Orong: 2017). Atau dengan kata lain, perubahan dan perkembangan yang terjadi mempengaruhi struktur bahasa. Bila dielaborasi berdasarkan situasi sekarang secara khusus dalam kaitannya dengan pandemi covid-19, dapat kita lihat bahwa sifat bahasa yang dinamis sangat nampak dan mencolok dirasakan. Dengan merebaknya pandemi covid-19, merebak pula istilah-istilah baru dalam hidup masyarakat indonesia. Istilah-istilah itu banyak yang merupakan istilah dari dan dipengaruhi oleh bahasa asing juga ada yang berupa akronim. Istilahistilah asing itu seperti, WFH (work from home), suspect, lockdown, social distancing, imported case, local transmission dan lain sebagainya.

\section{Kosa Kata Asing Pada Masa Pandemi}

Ada beberapa kosakata kata asing berupa singkatan, akronim, maupun istilah yang lazim digunakan pada masa peyebaran maupun penanganan pandemi COVID-19 (Devianty, 2020). Untuk lebih jelasnya mengenai ketiga kata tersebut beserta kaidah penulisannya, bisa diperhatikan pemaparan berikut.

a. Singkatan

Singkatan adalah hasil menyingkat (memendekkan), berupa huruf atau gabungan huruf (KBBI-Kemendikbud, 2020). Ada beberapa kaidah penulisan singkatan yang harus diperhatikan.

1) Singkatan nama orang, gelar, sapaan, jabatan, atau pangkat diikuti dengan tanda titik pada setiap unsur singkatan.

Misalnya: M. Amin (= Muhammad Amin), M.Pd. (= Magister Pendidikan), S.K.M. (= Sarjana Kesehatan Masyarakat), Sdr. (= saudara).

2) Singkatan yang terdiri atas huruf awal setiap kata nama lembaga pemerintah dan ketatanegaraan, lembaga pendidikan, badan atau organisasi, serta nama dokumen resmi ditulis dengan huruf kapital tanpa tanda titik. Misalnya: PBB (=Perserikatan BangsaBangsa), PGRI (=Persatuan Guru Republik Indonesia).

3) Singkatan yang terdiri atas huruf awal setiap kata yang bukan nama diri ditulis dengan huruf kapital tanpa tanda titik. Misalnya: PT 
(= Perseroan Terbatas), NIP (= Nomor Induk Pegawai).

4) Singkatan yang terdiri atas tiga huruf atau lebih diikuti dengan tanda titik. Misalnya: hlm. (= halaman), dkk. (= dan kawankawan).

b. Akronim

Akronim adalah kependekan yang berupa gabungan huruf atau suku kata atau bagian lain yang ditulis dan dilafalkan sebagai kata yang wajar. Beberapa kaidah penulisan akronim yang harus diperhatikan adalah sebagai berikut (Devianty, 2020).

1) Akronim nama diri yang terdiri atas huruf awal setiap kata ditulis dengan huruf kapital tanpa tanda titik. Misalnya: LIPI (= Lembaga Ilmu Pengetahuan Indonesia), PASI (= Persatuan Atletik Seluruh Indonesia).

2) Akronim nama diri yang berupa gabungan suku kata atau gabungan huruf dan suku kata dari deret kata ditulis dengan huruf awal kapital. Misalnya: Bappenas (= Badan Perencanaan Pembangunan Nasional), Sumut (= Sumatera Utara), Suramadu (= Surabaya-Madura).

3) Akronim bukan nama diri yang berupa gabungan huruf awal dan suku kata atau gabungan suku kata ditulis dengan huruf kecil. Misalnya: pemilu (= pemilihan umum), puskesmas (= pusat kesehatan masyarakat), tilang (= bukti pelanggaran) Beberapa akronim yang digunakan pada masa pandemic. Akronim asal kata terbentuknya akronim: webinar (= web seminar), nakes (= tenaga kesehatan), fasyankes $\quad(=$ fasilitas pelayanan masyarakat), daring (= dalam jaringan) https://kbbi.kemdikbud.go.id (2020).

c. Istilah

Pengertian istilah adalah kata atau gabungan kata yang dengan cermat mengungkapkan makna konsep, proses, keadaan, sifat yang khas dalam bidang tertentu (Harianto, 2010). Pendapat yang sama juga disampaikan Hariyanto bahwa istilah atau kosakata merupakan seluruh kata yang sudah didengar yang dimiliki oleh seorang pembicara yang telah disusun seperti kamus dan disertai dengan penjelasan yang singkat dan lengkap agar mudah dimengerti oleh pembaca. Dijelaskan juga dalam Kamus Besar Bahasa Indonesia bahwa istilah kata atau gabungan kata yang dengan cermat menggungkapkan makna konsep, proses, keadaan, atau sifat yang khas dalam bidang tertentu (KBBI.Kemendikbud, 2020). Penggunaan istilah pada masa pandemi sekarang ini banyak dijumpai menggunakan bahasa Inggris. Hal ini karena pemakaian kosakata dalam bentuk bahasa Inggris tersebut dirasa lebih memiliki nilai tinggi dan praktis dibandingkan dengan menggunakan bahasa Indonesia sendiri. Bahkan sebelum wabah pandemi ini terjadi pun, masyakat pengguna bahasa lebih suka menggunakan istilah asing saat berkomunikasi. Beberapa istilah bahasa Inggris yang sering digunakan pada masa pandemi Covid-19 seperti pada tabel berikut.

Tabel 1. Istilah Bahasa Inggris \& padanannya

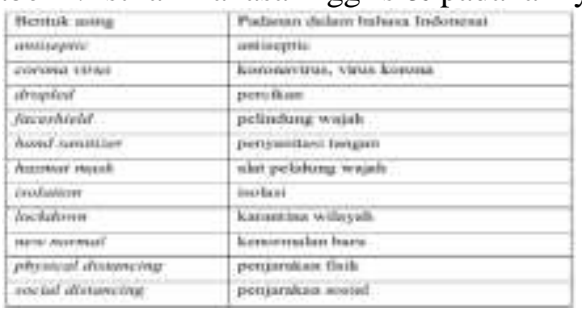

Sumber: penulis (2021)

\section{HASIL DAN PEMBAHASAN}

Teknik jajak pendapat secara random kepada masyarakat terkait pemahaman informasi dari istilahsitilah Covid -19 yang diinformasikan oleh pemerintah, Adapun jenis istilah Covid- dalam angket dikelompokkan berdasarkan jenis kosa kata dan jenis kata seperti pada tabel 1 berikut dengan tujuan untuk memudahkan proses pendataan pemahaman masyarakat dari setiap jawaban yang akan dianalisa dalam penelitian ini. Data yang dikumpulkan berupa daftar istilah covid-19 yang telah resmi disampaikan oleh pemerintah dan dijadikan sebagai dasar acuan penggunaan istilah yang menjadi variabel pada kuesioner, yakni: 1 induk variabel penggunaan Bahasa yang diterapkan dengan 4 bagian, yaitu: efisiensi elaborasi penggunaan akronim, penggunaan singkatan, penggunan mixing language, dan penggunaan istilah asing seperti diklasifikasi pada tampilan tabel berikut.

Tabel 1. Variable penggunaan Bahasa Covid

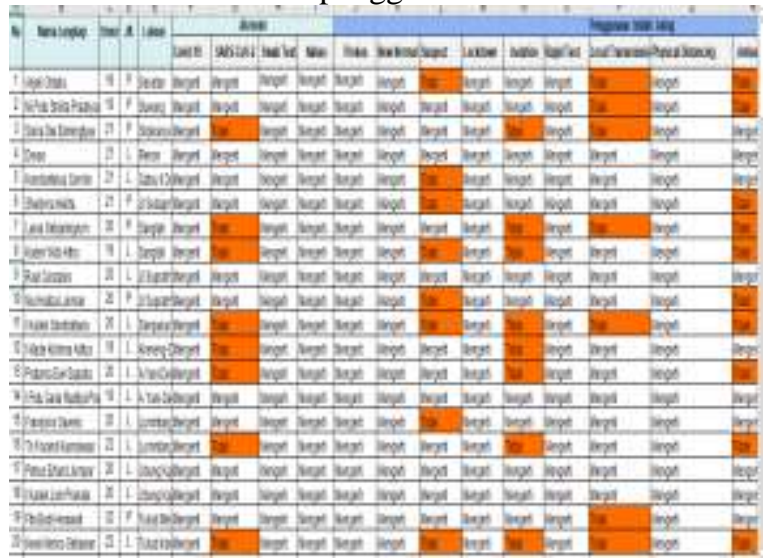

Sumber: Penulis (2021)

Hasil Analisa ini untuk mengetahui efisiensi proses elaborasi penggunaan istilah Bahasa Covid-19 bagi masyarakat sesuai dengan tujuan penelitian yang diusulkan pada skema PDM ini, seperti ditampilkan pada table berikut. 
Tabel 2. Variable penggunaan Akronim

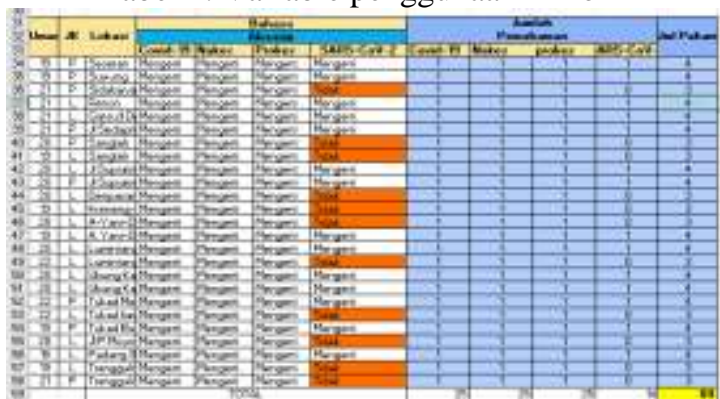

Sumber: Penulis (2021)

\section{Hasil Analisa Penggunaan Akronim, Singkatan, istilah asing, mixing langugaes}

Penggunaan akronim pada istilah covid sudah sering kali kita dengar, seperti data temuan pada tabel 2 , yaitu: nakes, prokes, Covid-19, SARS-Cov-2. Adapun prosentasi tingkat pemahaman masyarakat pada penggunaan istilah akronim ini dapat dihitung berdasarkan rumus:

\begin{tabular}{|c|c|}
\hline \multicolumn{2}{|c|}{ Tjr $=\operatorname{tr} \times \mathrm{i}$} \\
\hline $\mathrm{RP}=\frac{\mathrm{jp} \times 100}{\mathrm{Tjr}}$ & $\mathrm{rTP}=\underline{\mathrm{jtp} \times 100}$ \\
$\mathrm{tjr}$ \\
\hline
\end{tabular}

$\mathrm{tjr}=$ total jawaban responden

tr $=$ total responden

$\mathrm{i}=$ istilah

rp $=$ Responden Paham

rtp = Responden Tidak Paham

jp = jawaban Paham

jtp = jawaban tidak paham

Sehingga untuk mengetahui prosentase pada tabel 1 di atas: $\mathrm{tjr}=100 \% \rightarrow 25 \times 4=100(\mathrm{tjr}) . \mathrm{jp}=89(89 \%)$ maka jtp $=11(11 \%)$.

Penggunaan isitilah asing seperti swap test, new normal, suspect, lockdown, isolation, rapid test, local transmisiion, physical distancing, antiseptic, social distancing menjadi istilah yang masuk dalam daftar istilah asing Covid-19 yang banyak digunakan oleh masyarakat. $\rightarrow 25$ x $10=250$ (tjr). Sehingga jp =208 dengan prosentase $83,2 \%$ maka jtp $=42(16,8 \%)$.

Peran Mixing language atau lebih dikenal dengan "canpur kode" pada istilah Covid-19 seperti halnya pencampuran penggunaan istilah Bahasa Indonesia dengan bbahasa asing pada saat bersamaan. Seperti penggunaan mixing language pada istilah covid-19 ditemukan "screening pasien", "kasus suspect", "kasus probable". $\rightarrow 25$ x 3=75 (tjr). Sehingga jp =30 $(40 \%)$ maka jtp $=45(60 \%)$.

Penggunaan daftar singkatan seperti WFH (Work From Home), PCR (Polymerase Chain Reaction) seperti tampak pada tabel 5 merupakan produk Bahasa asing yang dikonsumsi masyarakat Indonesia, sedangkan daftar singkatan seperti PSBB, PKM, OTG, ODP, PDP, APD merupakan produk bahasa Indonesia. Penetapan penggunaan istilah ini telah diatur dalam kebijakan pemerintah, dengan memperhatikan beberapa hal kebahasaan, diantaranya penyampaian maksud, arti dan makna supaya dapat tersalurkan dengan cara disingkat, sehingga diharapkan dapat mempermudah pemahaman masyarahat dalam memahami makna dan lebih cepat beradaptasi dengan istilah Covid-19. Hasil Analisa khususnya pada tingkat pemahaman masyarakat berdasarkan kuesioner yang ditunjukkan pada tabel 5 di atas, dapat diprosentaseka: $\rightarrow 25 \mathrm{x}$ $8=200$ (tjr). Sehingga jp=172 (86\%) dan jtp=28 (14\%).

\section{Hasil Analisa Elaborasi Terhadap Pemahaman Masyarakat \& jajak pendapat via google form}

Berikut dilampirkan rekaman dasarkan hasil penyebaran kuesioner melalui google form yang berhasil didata oleh tim peneliti mengacu dari keempat variable support seperti ditunjukkan pada gambar berikut.

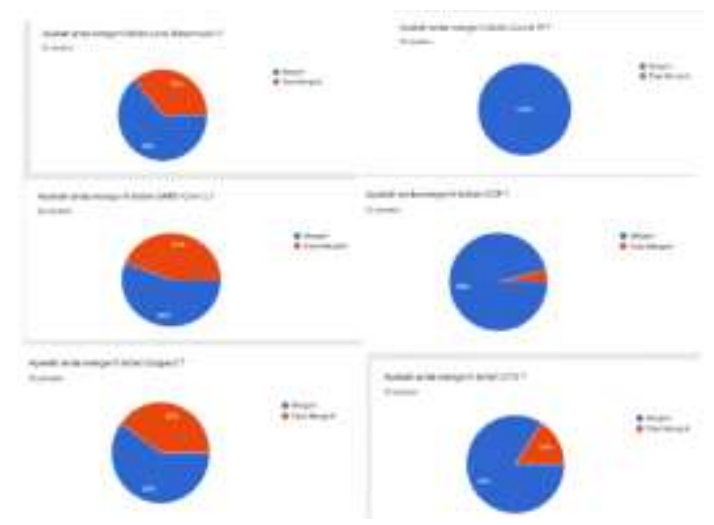

Sumber: penulis (2021)

Gambar 1. Hasil Jajak pendapat - app google form

Berdasarkan hasil perhitungan tingkat keterpahaman masyarakat terhadap analisa di atas, dapat disimpulkan bahwa tindak lanjut kelengkapan hasil analisa melalui hasil prosentase terhadap efisiensi pemahaman Bahasa Covid-19 seperti dideskripsikan pada bagan berikut.

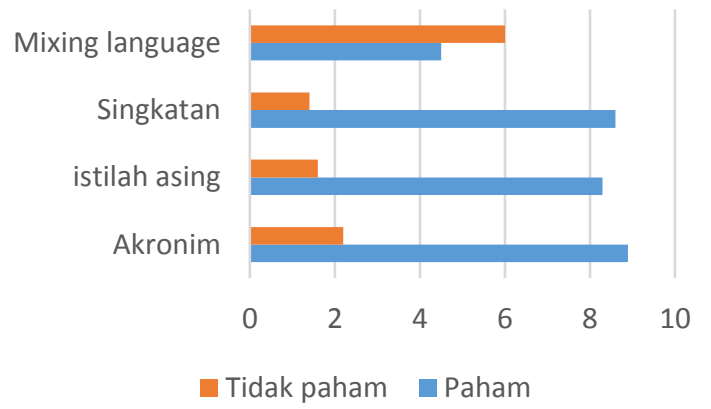

Sumber: penulis (2021)

Bagan 1. Prosentase terhadap efisiensi Pemahaman Penggunaan Bahasa Covid-19 


\section{KESIMPULAN}

Berdasarkan penjelasan pada bagan 1 dan mengacu pada data temuan seperti ditunjukkan pada tabel 1 sebelumnya bahwa deskripsi temuan penggunaan jenis kebahasaan terhadap tingkat pemahaman masyarakat di Denpasar dapat disimpulkan bahwa diantara keempat jenis support induk variabel penelitian khususnya pada penggunaan mixing language sangat mencolok hingga mencapai $60 \%$ ketidakpahaman masyarakat terhadap arti kata dengan jenis campur kode (mixing language) jika dibandingkan dengan ketiga dukungan variabel bahasa lainnya. Kisaran tingkat capaian keterpahaman terhadap ketiga support variabel lainnya masih sangat stabil, hal ini telah menjawab efisiensi elaborasi penggunaan Bahasa sangat efektif di masyarakat dengan tingkat capaian pemahaman masyarakat $\geq 60 \%$ hingga $\geq 80 \%$. Kondisi ini menunjukkan bahwa efisiensi penggunaan istilah akronim, singkatan, maupun istilah asing Covid-19 telah mampu dipahami dan diadaptasi oleh oleh masyarakat dalam komunikasi sehari-hari sehingga mempermudah mereka dalam menerapkan anjuran ataupun larangan bagi keamanan pada masa pandemi saat ini sesuai dengan kebijakan yang ditetapkan oleh pemerintah, tanpa merusak tatanan struktur Bahasa Indonesia sesuai dengan Amanah UUD 1945.

\section{REFERENSI}

Alfarizy, Putri. (2020). Kajian Budaya:Kebijakan Bahasa di Tengah Pandemi Covid19. Journal ANUVA (Volume 4) (3): 343-353, 2020 Copyright C2020, ISSN: 2598-3040 http://ejournal.undip.ac.id/index.php/anuva 343.

Allianz Indonesia. (2021). Inilah 8 Istilah Baru Yang Muncul Di Tengah Pandemi Covid-19. https://www.allianz.co.id/explore/detail/inilah8-istilah-baru-yang-muncul-di-tengah-pandemicovid-19/104739.

Devianty, Rima. (2020). Eksistensi Bahasa Indonesia Pada Masa Pandemi Nizhamiyah. Journal NIZHAMIYAH (Vol. X) No. 2, Juli - Desember 2020 e-ISSN: 2086-4205 27 p-ISSN: 2086-4205 39.

Hariyanto, B. (2010). "Istilah-Istilah Khusus dalam Chatting (Sebuah Analisis Sosiopragmatik)". Dalam Jurnal Adabiyyat (vol.9 no.2).
Yogyakarta: UIN Sunan Kalijaga. http:// ejournal.uinsu-

suka.ac.id/adab/Adabiyyat/article/view/793.

https://kbbi.kemendikbud.go.id

Komite Penanganan Covid-19 dan Pemulihan Ekonomi Nasional. (2020). Infografis COVID19 (11 November 2020). https://covid19.go.id/p/berita/infografis-covid19-11-november-2020. (diakses pada 11 November 2020).

Nissa, Rima Sekarini Immamun, dkk. (2020). "Pandemi Virus Corona, Ketahui Makna dan Tujuan IstilahCovid-19”. Dalam suara.com, 25 Maret 2020. https://www.suara.com/health/ 2020/03/25/144000/.

Sanga, Jhon F. (2020). Fungsi Bahasa dan Elaborasi Terhadap Istilah-istilah Asing Dalam Covid-19. https://thecolumnist.id/artikel/Fungsi Bahasa dan Elaborasi Terhadap Istilah-Istilah Asing dalam Covid-19 | The Columnist.

Sumarsono. (2017). Sosiolinguistik. Yogyakarta: Pustaka Pelajar.

Tim Pengembang Pedoman Bahasa Indonesia. (2016). Pedoman Umum Ejaan Bahasa Indonesia. Jakarta: Badan Pengembangan dan Pembinaan Bahasa Kementerian Pendidikan dan Kebudayaan.

\section{PROFIL PENULIS}

Penulis bernama Sri Widiastutik telah menyelesaikan Pendidikan S1 dan S2 di Universitas Udayana, dengan konsentrasi di bidang humaniora. Sejak tahun 2009 telah aktif mengajar, sebagai Dosen di STMIK STIKOM Indonesia hingga saat ini. Dengan motto "Hidup bukan sekedar menjadi, namun hidup adalah untuk memberi, walaupun sedikit namun besar manfaatnya bagi orang lain" semoga bisa menginspirasi pembaca. 